\title{
Penerapan Model Picture and Picture Berbantuan Media Roda Putar untuk Peningkatan Keterampilan Menulis Karangan Narasi Ekspositoris Siswa Kelas IV Sekolah Dasar
}

\section{Istiana Shofa ${ }^{1 *}$, Moh Kanzunnudin², Irfai Fathurohman ${ }^{3}$}

${ }^{1}$ Jurusan Pendidikan Sekolah Dasar, Universitas Muria Kudus, Kudus, Indonesia

${ }^{2,3}$ Pendidikan Bahasa dan Sastra Indonesia, Universitas Muria Kudus, Kudus, Indonesia

\author{
A R T I C L E I N F O \\ Article history: \\ Received 27 Agutus 2020 \\ Received in revised form \\ 30 Januari 2021 \\ Accepted 1 Maret 2021 \\ Available online 25 April \\ 2021
}

Kata Kunci:

Keterampilan Menulis,

Picture and Picture

Keywords:

Writing Skills, Picture and Picture

\begin{abstract}
A B S T R A K
Kurangnya keterampilan menulis siswa, dikarenakan pengggunaa model pembelajaran dan media pembelajaran yang kurang kreatif dan inovatif, sehingga membuat siswa menjadi mudah bosan. Tujuan penelitian ini adalah menganalisis penerapan model picture and picture berbantuan media roda putar terhadap peningkatan keterampilan menulis karangan narasi ekspositoris siswa. Penelitian ini termasuk kedalam jenis penelitian tindakan kelas (PTK). Subjek penelitian ini adalah keterampilan menulis karangan narasi ekspositoris yang melibatkan 21 siswa. Metode pengumpulan data yang digunakan yaitu wawancara, observasi, dan dokumentasi. Data kemudian dianalisis dengan teknik analisis data statistik kuantitatif. Hasil penelitian yakni keterampilan menulis muatan Bahasa Indonesia pada siklus pertama memperoleh persentase $50 \%$ berpredikat C, pada siklus kedua dengan persentase $76 \%$ berpredikat $\mathrm{B}$, sedangkan keterampilan menulis muatan IPS pada siklus pertama memperoleh persentase $49 \%$ predikat C, pada siklus kedua $76 \%$ predikat $\mathrm{B}$, dan kedua siklus ini telah berhasil serta terjadi peningkatan. Simpulan penelitian ini adalah model picture and picture
\end{abstract} berbantuan media roda putar dapat meningkatkan keterampilan menulis karangan narasi ekspositoris siswa. Implikasi penelitian ini adalah dapat melatih siswa cepat tanggap karena tertarik dengan gambar, adanya permainan bisa menambah motivasi belajar siswa, siswa lebih berkonsentrasi, menggali bakat dan potensi siswa, kerja sama siswa, rasa toleransi, dan yang paling utama meningkatkan keterampila menulis siswa.

\begin{abstract}
A B S T R A C T
Lack of students writing skills, because the users of learning models and learning media are less creative and innovative, so that students become bored easily. The purpose of this study was to analyze the application of the picture and picture model assisted by rotating wheel media to improve students expository narrative writing skills. This research belongs to the type of classroom action research (PTK). The subject of this research is the skill of writing expository narrative essays involving 21 students. The data collection methods used were interviews, observation and documentation. The data were then analyzed using quantitative statistical data analysis techniques. The results of the study were the skill of writing Indonesian content in the first cycle obtained a percentage of $50 \%$ predicate $C$, in the second cycle with a percentage of $76 \%$ predicate $B$, while the writing skills of social studies content in the first cycle obtained a percentage of $49 \%$ predicate $C$, in the second cycle $76 \%$ predicate $B$, and both of these cycles have been successful and there have been improvements. The conclusion of this research is that the picture and picture model assisted by the rotating wheel media can improve students expository narrative writing skills. The implication of this research is that it can train students to respond quickly because they are interested in pictures, the existence of games can increase student learning motivation, students concentrate more, explore students talents and potential, student cooperation, sense of tolerance, and most importantly improve students writing skills..
\end{abstract}




\section{Pendahuluan}

Keterampilan menulis merupakan salah satu keterampilan yang harus dikuasai oleh siswa khusunya siswa SD, sehingga diperlukan pembiasaan pengembangan keterampilan menulis, tujuannya untuk mengembangkan softskill dan hardskill siswa yang sangat diperlukan untuk masa depannya (Ningsih et al., 2019; Nugroho et al., 2019; Sutriyati et al., 2019). Keterampilan menulis siswa tidak bisa tumbuh secara instan namun melalui suatu proses pembiasaan, perlu dilakukan pelatihan sejak dini. Pentingnya keterampilan menulis ini karena jika keterampilan menulis dikuasai dengan baik maka akan bermanfaat bagi siswa dimasa mendatang (Fadliyatis et al., 2016; Riana \& Setiadi, 2017; Ulfah \& Soenarto, 2017). Siswa mampu memanfaatkan keterampilannya untuk membuat suatu karya ilmiah yang bermanfaat bagi orang banyak.

Berdasarkan hasil observasi diketahui sebesar $40 \%$ siswa yang memenuhi ketuntasan belajar, perolehan rata-rata hanya sebesar 40 untuk muatan bahasa Indonesia. Sedangkan untuk muatan IPS diperoleh persentase $45 \%$ dengan rata-rata nilai sebesar 45 . Masing-masing muatan ternyata tidak memenenuhi KKM. Perolehan di atas diketahui bahwa hasilnya didominasi oleh siswa yang belum mencapai Kriteria Ketuntasan Minimal (KKM) bisa dikatakan mendominasi. Berdasarkan studi dokumentasi diketahui bahwa keterampilan menulis siswa dilakukan dengan pengukuran lima aspek. Adapun lima aspek tersebut terdiri dari kerapihan tulisan, ejaan dan tata tulis, organisasi isi karangan, dan tata Bahasa. Permasalahan utama lerletak pada banyak siswa yang malas untuk menulis dan kurang cepat dalam menulis karena takut tertinggal. Siswa hanya diam dan memilih untuk meminjam tulisan temannya, sehingga diperlukan perbaikan pembelajaran. Pembelajaran yang kurang menarik minat siswa dan memperoleh respon yang kurang baik dari siswa seperti siswa yang merasa bosan. Model pembelajaran yang inovatif sebagai salah satu solusi untuk mengatasi permasalahan di atas. Salah satu model tersebut yakni model pembelajaran cooperative learning.

Pembelajaran cooperative learning memiliki karakteristik belajar bersama kelompok kecil, kelompok tersebut dibentuk secara heterogen (Darmawan, 2014; Said et al., 2019; Yoserizal \& Rahmi, 2019). Model cooperative learning mempunyai tipe yang berbeda-beda, salah satunya model picture and picture dalam pembelajaran. Peneliti memilih sebagai upaya perbaikan menggunakan model picture and picture. Model pembelajaran picture and picture merupakan model belajar dengan menggunakan gambar yang dipasang atau diurutkan menjadi urutan logis (Daryanti \& Taufina, 2020; Mayasari \& N, 2019; Rosmalem, 2017).

Keunggulan model model picture and picture menjadi hal yang sangat dipertimbangkan dalam pemilihan model ini. Keunggulan model picture and picture yakni siswa cepat tanggap karena tertarik dengan gambar, adanya permainan bisa menambah motivasi belajar siswa, siswa lebih berkonsentrasi, merasa asik, menggali bakat, potensi siswa, kerja sama siswa, rasa toleransi, dan yang paling utama meningkatkan keterampila menulis siswa (Astuti et al., 2020; Paramita et al., 2019; Rakasiwi, 2019).

Pelaksanaan model Picture and Picture dilakukan dengan beberapa langkah-langkah atau sintaks. Pertama, persentasi materi dengan guru menyampaikan materi pelajaran yang sesuai kompetensi. Kedua, pembentukan kelompok yang terdiri dari 7 orang yang bersifat heterogen. Ketiga, guru menempelkan gambar yang berkaitan dengan pelajarn. Keempat, guru meminta siswa menuliskan apa yang ada dalam pikiran siswa setelah melihat gambar. Kelima, menanyakan alasan siswa. Keenam, penghargaan. Ketujuh, menyimpulkan (Susanti \& Kusmariyani, 2017; Trisnawati et al., 2014; Utama \& Sari, 2015). Dengan pelaksanaan pembelajaran yang terdiri dari beberapa langkahlangkah tersebut dapat membuat suasana pembelajaran menjadi menyenangkan.

Suasana belajar yang menyenangkan dapat dilakukan dengan bantuan media pembelajaran, sehingga pembelajaran akan mencapai tujuan pembelajaran (Citrasmi et al., 2016; Maharwati, 2019; Sribawana et al., 2017). Sesuai dengan karakteristik model Picture and Picture yang berhubungan dengan gambar maka media roda putar sejalan dengan hal tersebut karena media roda putar menggunakan papan putar berwarna dan juga kartu yang menarik perhatian siswa. Kelebihan media roda putar menjadi hal yang diperhitungkan karena dengan media roda putar dapat membantu perkembangan berpikir dan menulis siswa (Handayani et al., 2017; Passalowongi, 2020; Tanjung, 2018).

Langkah-langkah media roda putar dirasa bisa membantu pelaksanaan model Picture and Picture. Langkah-langkahnya yakni siswa duduk berkelompok, perwakilan tiap anggota kelompok maju kedepan secara bergantian, siswa memutar roda putar dan mendapatkan nomor yang berhenti, selanjutnya siswa mendapat kartu berisi pertanyaan, dengan berdiskusi siswa menjawab pertanyaan 
yang ada dalam kartu, jika jawaban benar maka akan mendapat reward (Aprinawati, 2017; Dwicahyani et al., 2019; Khaulani et al., 2019).

Penelitian ini didukung beberapa penelitian terdahulu yang relevan dengan penelitian ini, seperti: (1) penelitian yang dilakukan oleh (Rosmalem, 2017), yang memperoleh hasil bahwa model pembelajaran picture and picture dapat meningkatkan aktivitas belajar siswa pada mata pelajaran Seni Budaya; (2) penelitian yang dilakukan oleh (Daryanti \& Taufina, 2020), yang memperoleh hasil bahwa penggunaan media pembelajaran dalam model picture and picture dinyatakan dapat meningkatkan hasil belajar siswa; (3) penelitian yang dilakukan oleh (Rakasiwi, 2019), yang memperoleh hasil bahwa media komik dengan metode picture and picture dinyatakan dapat meningkatkan keterampilan literasi matematika siswa.

Tujuan dilaksanakannya penelitian ini untuk menganalisis penerapan model picture and picture berbantuan media roda putar terhadap peningkatan keterampilan menulis karangan narasi ekspositoris siswa kelas IV SD 1 Jati Wetan Kudus semester II Tahun Pelajaran 2019/2020.

\section{Metode}

Penelitian ini termasuk kedalam jenis penelitian tindakan kelas (PTK). Desain PTK ini terdiri dari tahapan perencanaan, pelaksanaan, pengamatan dan refleksi. Penelitian tindakan kelas ini dilakukan selama dua siklus, yakni siklus I dan siklus II. Penelitian ini diilaksanakan di Sekolah Dasar Negeri 1 Jati Wetan Kudus.

Subjek penelitian ini adalah keterampilan menulis karangan narasi ekspositoris yang melibatkan 21 siswa. Adapun tujuan penelitian ini untuk menganalisis penerapan model picture and picture berbantuan media roda putar terhadap peningkatan keterampilan menulis karangan narasi ekspositoris siswa.

Metode pengumpulan data yang digunakan yaitu wawancara, observasi, dan dokumentasi. Metode pengumpulan data dengan beberapa cara. Cara yang pertama dengan menggunakan wawancara. Wawancara digunakan untuk memeperoleh data awal. Cara kedua dengan melakukan observasi. Teknik ini dilakukan pada saat observasi awal dan keterampilan menulis siswa dalam pelaksanaan pembelajaran. Pedoman observasi dengan aspek kerapihan tulisan, ejaan dan tata tulisan, banyaknya kalimat pada tiap paragraph, dan tata bahasa. Cara ketiga dengan dokumentasi berupa data-data penunjang penelitian.

Data yang telah diperoleh, kemudian dianalisis dengan teknik analisis data statistik kuantitatif. Sumber data pada penelitian ini melipuri data primer dan data sekunder. Data primer merupakan data yang diperoleh lansung oleh penelti. Adapun macam-macam datanya meliputi hasil observasi keterampilan menulis siswa dan hasil observasi awal. Sedangkan data sekunder merupakan data pendukung seperti hasil dokumentasi. Data ini berupa keterampilan menulis siswa terkait muatan Bahasa Indonesia dan IPS dengan aspek keterampilan menulis.

\section{Hasil dan Pembahasan}

Penelitian tindakan kelas ini dilakukan selama dua siklus, yakni siklus I dan siklus II. Siklus I, perencanaan penelitian ini diawali dengan mencari permasalahan pada sekolah dasar. Kemudaian dilanjutkan dengan pembuatan rencana pembelajaran. Adapun rencana tersebut terdiri dari silabus, RPP, lembar observasi, rubrik pembelajaran. pedoman wawancara dan media roda putar, serta hal-hal yang menunjang pelaksanaan penelitian seperti sumber belajar.

Pelaksanaan penelitian ini berupa persentasi materi dengan guru menyampaikan konten pembelajaran. Siswa berkelompok sejumlah 7 siswa secara heterogen. Kemudian diberikan tugas kelompok dan dilanjutkan diskusi untuk menyelesaikan permasalahan. Kemudian penghargaan kelompok dengan memeberikan penghargaan kelompok yang bermain ular tangga.

Tahap observasi dilaksanakan pada saat pelaksanaan pembelajarana. Observasi berarti kegiatan mengamati keadaan kelas, apa saja yang terjadi di kelas, masalah apa yang muncul, dan halhal menarik apa yang muncul. Observasi ini beracuan pada pedoman observasi yang telah disusun peneliti dengan panduan indikator akitivitas belajar dan keterampilan mengajar guru, juga keterampilan menulis. Kegiatan ini dilakuka oleh teman sejawat dan guru kelas.

Hasil dari pengamatan kemudian diolah selanjutnya dilakukan analisis masalah pembelajaran baik itu kesulitan belajar siswa maupun kesulitan mengajar guru ataupun kekurangan sarana 
prasarana. Kegiatan ini disebut kegiatan refleksi. Kegiatan refleksi bertujuan untuk mengevaluasi kegiatan pembelajaran dan menemukan masalah yang terjadi kemudian diupayakan solusi pemecahan masalahnya.

Pelaksanaan tindakan tiap siklusnya dengan muatan Bahasa Indonesia dan IPS. Guru melakukan perencanaan dengan menyusun silabus dan RPP tema 8 Daerah Tempat Tinggalku Subtema 1 dan 2 pembelajaran 3 dan 4, guru membuat media roda putar, dan membuat pedoman observasi keterampilan menulis. Pada pelaksanaannya siswa memperhatikan materi pembelajaran yang disampaikan oleh guru, siswa membentuk kelompok secara heterogen atas arahan guru yang terdiri dari 7 anggota kelompok, setelah itu siswa menerima tugas dari guru dan mendisuksikannya, siswa melakukan kuis dengan menggunakan media roda putar. Media roda putar dilakukan dengan masing-masing bergantian memutar papan dilanjutkan dengan menjawab pertanyaan yyang ada pada kartu sesuai nomor yang diperoleh. Siswa menjawab atau melakukan tugas yang terdapat pada kartu. Permainan berulang seperti itu hingga semua perwakilan kelompok mendapat giliran. Kelompok yang berhasil menjawab mendapatkan skor. Kemudian skor diakumulasikan. Pemenang merupakan kelompok dengan perolehan skor tertinggi dan memperoleh penghargaan.

Tahap observasi dibantu oleh teman sejawat dengan mengamati keterampilan menulis siswa pada saat pembelajaran. Berdasarkan data awal (prasiklus) diperoleh persentase muatan Bahasa Indoesia sebesar $40 \%$ dalam kriteria kurang. Penyebabnya kurang keterampilan menulis dan pembalajaran berpusat pada guru. Hasil keterampilan menulis muatan Bahasa Indonesia dan IPS pada siklus I dapat disajikan pada Tabel 1.

Tabel 1. Keterampilan Menulis Siswa Muatan Bahasa Indonesia Siklus I

\begin{tabular}{|c|c|c|c|c|c|c|c|c|c|c|}
\hline \multirow{2}{*}{ Aspek } & \multicolumn{5}{|c|}{ Pertemuan 1} & \multicolumn{5}{|c|}{ Pertemuan 2} \\
\hline & 5 & 4 & 3 & 2 & 1 & 5 & 4 & 3 & 2 & 1 \\
\hline Organisasi Penulisan & 0 & 0 & 2 & 12 & 1 & 0 & 2 & 8 & 5 & 0 \\
\hline Ketepatan Diksi & 0 & 0 & 6 & 8 & 1 & 0 & 2 & 9 & 4 & 0 \\
\hline Ketepatan Kalimat & 0 & 0 & 5 & 10 & 0 & 0 & 0 & 9 & 6 & 0 \\
\hline Ejaan dan Tata Tulis & 0 & 0 & 7 & 8 & 0 & 0 & 0 & 12 & 3 & 0 \\
\hline Total & $\mathbf{0}$ & $\mathbf{0}$ & 21 & 38 & $\mathbf{0}$ & $\mathbf{0}$ & 4 & 28 & 18 & $\mathbf{0}$ \\
\hline Jumlah Skor & \multicolumn{5}{|c|}{184} & \multicolumn{4}{|c|}{197} & \\
\hline Rata-Rata Nilai & \multicolumn{5}{|c|}{45} & \multicolumn{4}{|c|}{54} & \\
\hline Persentase & \multicolumn{5}{|c|}{$45 \%$} & \multicolumn{5}{|c|}{$54 \%$} \\
\hline Kriteria & \multicolumn{5}{|c|}{ Cukup } & \multicolumn{5}{|c|}{ Cukup } \\
\hline Persentase Siklus I & \multicolumn{10}{|c|}{$50 \%$} \\
\hline Kriteria & & & & & $\mathrm{Cul}$ & & & & & \\
\hline
\end{tabular}

Berdasarkan Tabel 1, diketahui bahwa terjadi peningkatan setiap pertemuannya. Diketahui pertemuan pertama memperoleh $45 \%$ dan pertemuan kedua memperoleh $54 \%$. Hasil tersebut diketahui peningkatannya sebesar $9 \%$. Persentase muatan Bahasa Indonesia sebesar $50 \%$ artinya belum memenuhi indikator keberhasilan. Keterampilan menulis siswa muatan IPS siklus I disajikan pada Tabel 2.

Dari Tabel 2, dapat diketahui bahwa setiap pertemuan mengalami peningkatan. persentase siklus I sebesar $49 \%$ belum memenuhi indikator keberhasilan. Dengan rincian pertemuan pertama memperoleh $47 \%$ dan pertemuan dua memperoleh 51\%. Perbaikan-perbaikan perlu dilaksanakan pada siklus II, Pada siklus I ini siswa belum terbiasa memperoleh pembelajaran yang cenderung pada keaktifan siswa, sehingga dilakukan perbaikan pada siklus II.

Perencanaan penelitian pada siklus II mengacu pada pertimbangan hasil refleksi dari siklus I. Selanjutnya dilakukan beberapa persiapan diantaranya menyusun silabus dan RPP, menyiapkan sumber belajar dan media roda putar serta membuat pedoman observasi, lembar observasi, dan rubrik penilaian. Guru senantiasa mempersiapkan hal tersebut guna keberhasilan pembelajaran. 
Tabel 2. Keterampilan Menulis Siswa Muatan IPS Siklus I

\begin{tabular}{|c|c|c|c|c|c|c|c|c|c|c|}
\hline \multirow{2}{*}{ Aspek } & \multicolumn{5}{|c|}{ Pertemuan 1} & \multicolumn{5}{|c|}{ Pertemuan 2} \\
\hline & 5 & 4 & 3 & 2 & 1 & 5 & 4 & 3 & 2 & 1 \\
\hline Ketepatan Kelogisan & 0 & 0 & 3 & 12 & 1 & 0 & 0 & 6 & 9 & 0 \\
\hline Ketepatan Diksi & 0 & 0 & 8 & 7 & 1 & 0 & 0 & 6 & 9 & 0 \\
\hline Kelancaran Menulis & 0 & 0 & 6 & 9 & 0 & 0 & 1 & 5 & 9 & 0 \\
\hline Komunikatif/ Kontak Mata & 0 & 0 & 8 & 7 & 0 & 0 & 0 & 11 & 4 & 0 \\
\hline Volume Suara & 0 & 0 & 5 & 10 & 0 & 0 & 0 & 7 & 8 & 0 \\
\hline Percaya Diri & 0 & 0 & 3 & 12 & 0 & 0 & 0 & 6 & 9 & 0 \\
\hline Total & $\mathbf{0}$ & $\mathbf{0}$ & 28 & 65 & $\mathbf{0}$ & $\mathbf{0}$ & 6 & 53 & 31 & $\mathbf{0}$ \\
\hline Jumlah Skor & \multicolumn{5}{|c|}{189} & \multicolumn{5}{|c|}{207} \\
\hline Rata-Rata Nilai & \multicolumn{5}{|c|}{47} & \multicolumn{5}{|c|}{51} \\
\hline Persentase & \multicolumn{5}{|c|}{$47 \%$} & \multicolumn{5}{|c|}{$51 \%$} \\
\hline Kriteria & \multicolumn{5}{|c|}{ Cukup } & \multicolumn{5}{|c|}{ Cukup } \\
\hline Persentase Siklus I & \multicolumn{10}{|c|}{$49 \%$} \\
\hline Kriteria & \multicolumn{10}{|c|}{ Cukup } \\
\hline
\end{tabular}

Pelaksanaan pembelajaran dilakukan dengan tiga kegiatan yakni kegiatan awal, kegiatan inti, dan kegiatan penutup. Kegiatan awal dilakukan dengan apersepsi, pemberian motivasi dan menumbuhkan rasa nasionalisme serta literasi. Kegiatan inti dengan melakukan tahap-tahap model Picture and Picture dengan menggunakan media roda putar sesuai dengan materi yang diajarkan. Tahap-tahapnya meliputi persentasi materi, pembentukan kelompok, permainan roda putar dan penghargaan kelompok. Kegiatan penutup berupa evaluasi, refleksi dan menyimpulkan pembeljaran.

Selanjutnya tahap observasi dilakukan dengan mengamati keterampilan menulis siswa dengan menggunakan pedoman yang telah disusun. Kegiatan pengamatan dilakukan bersamaan dengan kegiatan pelaksanaan pembelajaran. Kegiatan ini dilakukan oleh teman sejawat beserta pengambilan foto-foto kegiatan pembelajaran.

Hasil observasi kemudian dikumpulkan dan dianalisis untuk disimpulkan perolehan pada siklus II. Kemudian peneliti mempertimbangkan apakah dibutuhkan penambahan siklus atau cukup pada siklus II saja. Keputusan ini diambil oleh peneliti, jika merasa sudah cukup maka berhenti pada siklus II saja. Keterampilan menulis siswa muatan Bahasa Indonesia siklus II dapat disajikan pada Tabel 3.

Tabel 3. Keterampilan Menulis Siswa Muatan Bahasa Indonesia Siklus II

\begin{tabular}{|c|c|c|c|c|c|c|c|c|c|c|}
\hline \multirow{2}{*}{ Aspek } & \multicolumn{5}{|c|}{ Pertemuan 1} & \multicolumn{5}{|c|}{ Pertemuan 2} \\
\hline & 5 & 4 & 3 & 2 & 1 & 5 & 4 & 3 & 2 & 1 \\
\hline Ketepatan Kelogisan & 0 & 0 & 5 & 10 & 0 & 1 & 11 & 3 & 0 & 0 \\
\hline Ketepatan Diksi & 1 & 6 & 8 & 0 & 0 & 1 & 12 & 2 & 0 & 0 \\
\hline Kelancaran Menulis & 0 & 10 & 5 & 0 & 0 & 1 & 12 & 2 & 0 & 0 \\
\hline Komunikatif/ Kontak Mata & 0 & 7 & 8 & 0 & 0 & 2 & 12 & 1 & 0 & 0 \\
\hline Total & 1 & 33 & 26 & 10 & $\mathbf{0}$ & 5 & 44 & 8 & $\mathbf{0}$ & $\mathbf{0}$ \\
\hline Jumlah Skor & \multicolumn{5}{|c|}{309} & \multicolumn{5}{|c|}{325} \\
\hline Rata-Rata Nilai & \multicolumn{5}{|c|}{71} & \multicolumn{5}{|c|}{78} \\
\hline Persentase & \multicolumn{5}{|c|}{ 71\% } & \multicolumn{5}{|c|}{$80 \%$} \\
\hline Kriteria & \multicolumn{5}{|c|}{ Baik } & \multicolumn{5}{|c|}{ Baik } \\
\hline Persentase Siklus II & \multicolumn{10}{|c|}{$76 \%$} \\
\hline Kriteria & \multicolumn{10}{|c|}{ Baik } \\
\hline
\end{tabular}

Berdasarkan tabel tersebut diketahui bahwa terjadi peningkatan setiap pertemuannya. Diketahui pertemuan pertama memperoleh $71 \%$ dan pertemuan kedua memperoleh $80 \%$. Hasil tersebut diketahui peningkatannya sebesar 9\%. Persentase muatan Bahasa Indonesia sebesar 76\% artinya telah memenuhi indikator keberhasilan. Hal ini terjadi karena perbaikan masalah-masalah yang terjadi pada siklus I. Keterampilan menulis siswa muatan IPS Siklus II disajikan pada Tabel 4. 
Tabel 4. Keterampilan Menulis Siswa Muatan IPS Siklus II

\begin{tabular}{|c|c|c|c|c|c|c|c|c|c|c|}
\hline \multirow[t]{2}{*}{ Aspek } & \multicolumn{5}{|c|}{ Pertemuan 1} & \multicolumn{5}{|c|}{ Pertemuan 2} \\
\hline & 5 & 4 & 3 & 2 & 1 & 5 & 4 & 3 & 2 & 1 \\
\hline Ketepatan Kelogisan & 1 & 0 & 5 & 9 & 0 & 3 & 10 & 2 & 0 & 0 \\
\hline Ketepatan Diksi & 2 & 7 & 6 & 0 & 0 & 2 & 11 & 2 & 0 & 0 \\
\hline Kelancaran Berbicara & 1 & 9 & 5 & 0 & 0 & 2 & 11 & 2 & 0 & 0 \\
\hline Komunikatif/Kontak Mata & 0 & 7 & 8 & 0 & 0 & 4 & 10 & 1 & 0 & 0 \\
\hline Total & 4 & 23 & 24 & 9 & $\mathbf{0}$ & 11 & 42 & 7 & $\mathbf{0}$ & $\mathbf{0}$ \\
\hline Jumlah Skor & \multicolumn{5}{|c|}{310} & \multicolumn{5}{|c|}{337} \\
\hline Rata-Rata Nilai & \multicolumn{5}{|c|}{73} & \multicolumn{5}{|c|}{82} \\
\hline Persentase & \multicolumn{5}{|c|}{$73 \%$} & \multicolumn{5}{|c|}{$82 \%$} \\
\hline Kriteria & \multicolumn{5}{|c|}{ Baik } & \multicolumn{5}{|c|}{ Sangat Baik } \\
\hline Persentase Siklus II & \multicolumn{10}{|c|}{$78 \%$} \\
\hline Kriteria & \multicolumn{10}{|c|}{ Baik } \\
\hline
\end{tabular}

Perolehan Tabel 4, diketahu bahwa siklus II muatan IPS mengalamu peningkatan tiap pertemuannya dengan peningkatannya 9\%. Selanjutnya pertemuan 1 dan 2 diakumulasikan. Sehingga memperoleh hasil 78\% yang artinya pembelajaran berhasil karena sudah memenuhi indikator keberhasilan lebih dari 70\%. Pada siklus II ini mendapatkan hasil yang lebih baik dibandingkan siklus I, sehingga antara siklus I dan II mengalami peningkatan.

Berdasarkan perolehan keterampilan menulis siswa muatan Bahasa Indonesia dan IPS diketahui keduanya mengalami peningkatan. Masing-masing peningkatan terjadi pada setiap pertemuan. Sehingga terjadi juga peningkatan pada setiap siklusnya. Setelah kegiatan observasi dilakukan, kemudian guru melakukan refleksi. Hasil refleksi siklus I ditemukan beberapa hambatan terkait siswa yang masih pasif sehingga guru lebih mengaitkan materi dengan kehidupan sehari-hari, kurangnya keaktivan siswa dalam mengikuti intruksi guru sehingga guru kurang maksimal dalam menjelaskan prosedur dengan benar, kurangnya guru mengkondisikan siswa sehingga guru menarik perhatian siswa, waktu yang kurang efisien sehingga guru memberikan batas wkatu pada kegiatan siswa, dan kurang maksimalnya guru dalam membimbing siswa sehingga guru berkeliling dan bertanya kepada siswa tentang tugas yang diberikan.

Hasil refleksi tersebut dijadikan pertimbangan dalam pelaksanaan siklus II. Kegiatan reflektif bertujuan untuk meningkatkan profesionalitas guru, dan menjadikan mutu lebih berkualitas. Untuk peningkatan keterampilan menulis siswa tiap siklus disajikan pada Gambar 1.

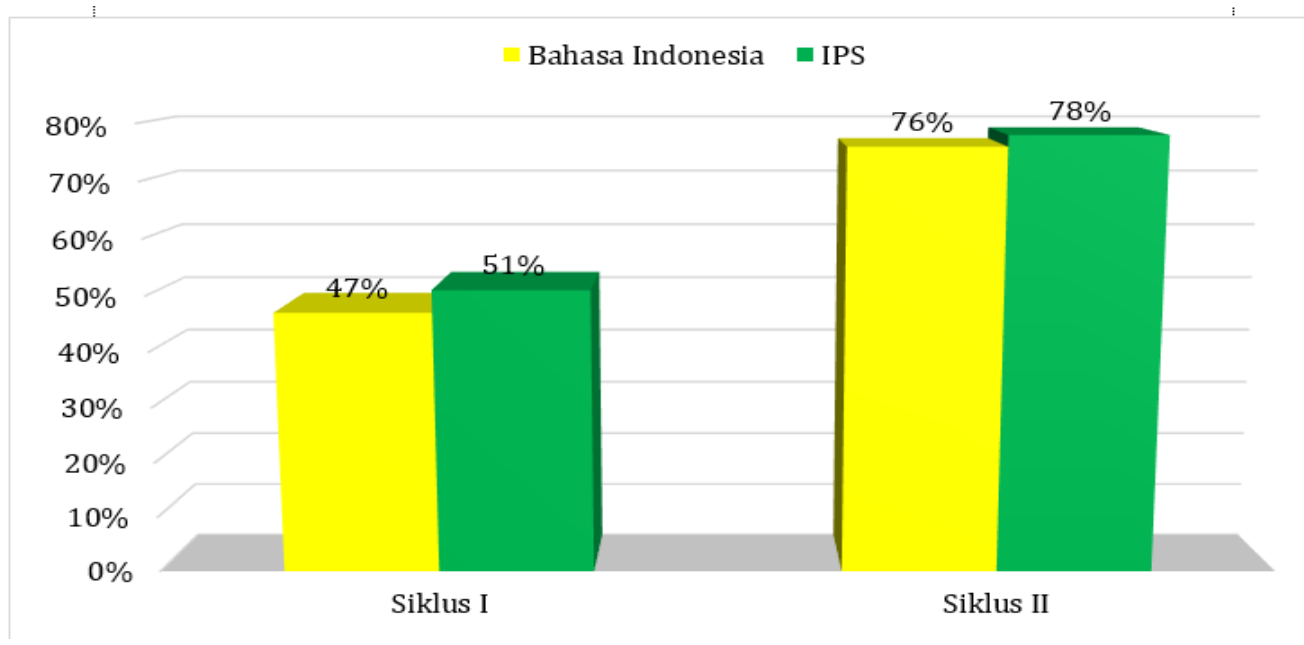

Gambar 1. Peningkatan Keterampilan Menulis Siswa tiap Siklus

Gambar 1, menunjukan peningkatan tiap siklusnya. Hasil dari itu menunjukkan bahwa pada siklus II pada muatan Bahasa Indonesia memperoleh persentase 76\%, sedangkan pada muatan IPS meperoleh peresentase 78\%. Berdasarkan hasil tiap siklusnya diketahui bahwa pada muatan Bahasa 
Indonesia terjadi peningkatan persentase sebesar $26 \%$ dan muatan IPS terjadi peningkatan persentase sebesar 22\%. Hasil siklus II telah berhasil dikarenakan persentasenya melabihi $70 \%$ setiap muatannya.

Indikator yang diamati pertama yakni ketepatan kelogisan (penalaran). Kegiatan yang terjadi dengan siswa menyampaikan pemikirannya melalui tulisan mengenai permasalahan yang diberikan. Pembiasaan tersebut mampu meningkatkan penalaran siswa. Sehingga keterampilan menulisakan lebih maksimal dengan penalaran yang berkembang optimal. Ketepatan penalaran terdiri dari kelogisan dan kesatuan ide, ketepatan penalaran ini tidak ditemukan dalam karangan siswa (Dewi \& Yuliana, 2018; Kurniasari, 2017; Puspidalia, 2012).

Indikator kedua yakni ketepatan diksi (pilihan kata). Berkaitan dengan ketepatan diksi diperoleh siswa dalam kegiatan membaca dan menyimak. Siswa belajar bagaimana memilih kata pada setiap paragraf yang ditulisnya. Sehingga pada saat permainan roda putar itulah keterampilan menulis di lihat juga didalamnya ketepatan diksi diterapkan. Pada aspek diksi (pilihan kata), guru guru dapat melatih siswa dengan cara beberapa kali menyuruh siswa untuk membaca buku siswa maupun modul (Sudaryanto, 2014; Suwartini \& Fujiastuti, 2017; Wahyuni, 2014).

Indikator ketiga yakni ketepata organisasi. Ketepatan orgaisasi kata menjadi salah satu penentu informasi akan diterima sesuai apa yang dimaksudkan. Untuk itu perlu sekali siswa membiasakan hal-hal yang menunjang ketepatan orgaisasi kata untuk eningkatkan keterampilan menulis (Mahardika, 2018; Rosini, N. M., Yudana, I. M., \& Agung, 2018; Yuanta, 2017). Salah satunya dengan memanfaatkan penggunaan model pembelajaran Picture and Picture berbantuan media roda putar.

Model Picture and Picture berbantuan media roda putar menjadikan keterampilan menulis karangan narasi ekspositoris siswa meningkat. Hal tersebut berdasarkan peningkatan tiap-tiap aspek pada setiap siklusnya. Mulai aspek ketepatan kelogisan (penalaran), ketepatan diksi (pilihan kata), ketepatan organisasi bahasa, ejaan dan tata tulis. Keterampilan menulis siswa dapat ditingkatkan melalui menerapkan Picture and Picture (Owon \& Adi, 2017; Suhartini, 2015; Ulfah \& Soenarto, 2017).

Pelaksanaan model Picture and Picture dilakukan dengan beberapa langkah-langkah atau sintaks. Pertama, persentasi materi dengan guru menyampaikan materi pelajaran yang sesuai kompetensi. Kedua, pembentukan kelompok yang terdiri dari 7 orang yang bersifat heterogen. Ketiga, guru menempelkan gambar yang berkaitan dengan pelajarn. Keempat, guru meminta siswa menuliskan apa yang ada dalam pikiran siswa setelah melihat gambar. Kelima, menanyakan alasan siswa. Keenam, penghargaan. Ketujuh, menyimpulkan (Susanti \& Kusmariyani, 2017; Trisnawati et al., 2014; Utama \& Sari, 2015). Dengan pelaksanaan pembelajaran yang terdiri dari beberapa langkahlangkah tersebut dapat membuat suasana pembelajaran menjadi menyenangkan.

Suasana belajar yang menyenangkan dapat dilakukan dengan bantuan media pembelajaran, sehingga pembelajaran akan mencapai tujuan pembelajaran (Citrasmi et al., 2016; Maharwati, 2019; Sribawana et al., 2017). Sesuai dengan karakteristik model Picture and Picture yang berhubungan dengan gambar maka media roda putar sejalan dengan hal tersebut karena media roda putar menggunakan papan putar berwarna dan juga kartu yang menarik perhatian siswa. Kelebihan media roda putar menjadi hal yang diperhitungkan karena dengan media roda putar dapat membantu perkembangan berpikir dan menulis siswa (Handayani et al., 2017; Passalowongi, 2020; Tanjung, 2018).

Langkah-langkah media roda putar dirasa bisa membantu pelaksanaan model Picture and Picture. Langkah-langkahnya yakni siswa duduk berkelompok, perwakilan tiap anggota kelompok maju kedepan secara bergantian, siswa memutar roda putar dan mendapatkan nomor yang berhenti, selanjutnya siswa mendapat kartu berisi pertanyaan, dengan berdiskusi siswa menjawab pertanyaan yang ada dalam kartu, jika jawaban benar maka akan mendapat reward (Aprinawati, 2017; Dwicahyani et al., 2019; Khaulani et al., 2019).

Penelitian ini didukung beberapa penelitian terdahulu yang relevan dengan penelitian ini, seperti: (1) penelitian yang dilakukan oleh (Rosmalem, 2017), yang memperoleh hasil bahwa model pembelajaran picture and picture dapat meningkatkan aktivitas belajar siswa pada mata pelajaran Seni Budaya; (2) penelitian yang dilakukan oleh (Daryanti \& Taufina, 2020), yang memperoleh hasil bahwa penggunaan media pembelajaran dalam model picture and picture dinyatakan dapat meningkatkan hasil belajar siswa; (3) penelitian yang dilakukan oleh (Rakasiwi, 2019), yang memperoleh hasil 
bahwa media komik dengan metode picture and picture dinyatakan dapat meningkatkan keterampilan literasi matematika siswa.

Implikasi dari pelaksanaan penelitian tindakan kelas (PTK) ini adalah dapat melatih siswa cepat tanggap karena tertarik dengan gambar, adanya permainan bisa menambah motivasi belajar siswa, siswa lebih berkonsentrasi, menggali bakat dan potensi siswa, kerja sama siswa, rasa toleransi, dan yang paling utama meningkatkan keterampila menulis siswa.

\section{Simpulan}

Berdasarkan hasil penelitian ini dapat disimpulkan penelitian bahwa model picture and picture berbantuan media roda putar dapat meningkatkan keterampilan menulis karangan narasi ekspositoris siswa. Implikasi penelitian ini adalah dapat melatih siswa cepat tanggap karena tertarik dengan gambar, adanya permainan bisa menambah motivasi belajar siswa, siswa lebih berkonsentrasi, menggali bakat dan potensi siswa, kerja sama siswa, rasa toleransi, dan yang paling utama meningkatkan keterampila menulis siswa.

\section{Daftar Pustaka}

Aprinawati, I. (2017). Penggunaan Media Gambar Seri Untuk Meningkatkan Kemampuan Berbicara Anak Usia Dini. Jurnal Obsesi: Jurnal Pendidikan Anak Usia Dini, 1(1), 72. https://doi.org/10.31004/obsesi.v1i1.33.

Astuti, H. P., Nugroho, A. A. E., \& Dewi, N. A. R. (2020). Penerapan Model Pembelajaran Picture and Picture Berbasis Keanekaragaman Hayati Dalam Pembentukan Empati Anak Usia Dini. Intuisi : Jurnal Psikologi Ilmiah, 12(1), 66-74. https://doi.org/10.15294/intuisi.v12i1.23573.

Citrasmi, N. W., Wirya, N., \& Tegeh, I. M. (2016). Pengaruh Model Pembelajaran Scramble Berbantuan Media Gambar Terhadap Hasil Belajar IPA Di SD. Jurnal Mimbar PGSD Undiksha, 4(2). https://doi.org/10.23887/jjpgsd.v4i2.8425.

Darmawan, H. (2014). Peningkatan Kreatifitas Mahasiswa Dalam Merancang Media Pembelajaran Multimedia IPA Berbasis Animasi Melalui Model Cooperative Learning. Jurnal Edukasi, 12(2), 193-204. https://doi.org/10.31571/edukasi.v12i2.155.

Daryanti, D., \& Taufina, T. (2020). Penggunaan Media Pembelajaran dalam Model Picture and Picture untuk meningkatkan Hasil Belajar Siswa. Jurnal Basicedu, 4(2), 484-490. https://doi.org/10.31004/basicedu.v4i2.368.

Dewi, T. K., \& Yuliana, R. (2018). Pengembangan Media Pembelajaran Scrapbook Materi Karangan Deskripsi Mata Pelajaran Bahasa Indonesia Kelas Iii Sekolah Dasar. Refleksi Edukatika : Jurnal Ilmiah Kependidikan, 9(1). https://doi.org/10.24176/re.v9i1.2804.

Dwicahyani, N. M., Wiarta, I. W., \& Ardana, I. K. (2019). Penerapan Model Pembelajaran Nht Berbantuan Media Gambar Meningkatkan Penguasaan Kompetensi Ips. Journal for Lesson and Learning Studies, 2(1), 102-110. https://doi.org/10.23887/jlls.v2i1.17326.

Fadliyatis, K. S., Harsiati, T., \& Hasanah, M. (2016). Pengembangan Instrumen Asesmen Autentik Keterampilan Menulis Teks Cerpen Dan Teks Fabel Untuk Siswa Smp / Mts. Jurnal Pendidikan, 1(3), 421-427. https://doi.org/http://dx.doi.org/10.17977/jp.v1i3.6168.

Handayani, N. M. D., Ganing, N. N., \& Suniasih, N. W. (2017). Model Pembelajaran Picture and Picture Berbantuan Media Audio-Visual Terhadap Kompetensi Pengetahuan IPA. Journal of Education Technology, 1(3), 176-182. https://doi.org/10.23887/jet.v1i3.12502.

Khaulani, F., Noviana, E., \& Witri, G. (2019). Penerapan Metode Brainstorming Dengan Bantuan Media Gambar Grafis Untuk Meningkatkan Hasil Belajar PKN Siswa Kelas V SD Negeri 009 Pulau Kecamatan Bangkinang Kabupaten Kampar. Jurnal Pajar (Pendidikan Dan Pengajaran), 3(1), 18-25. https://doi.org/10.33578/pjr.v3i1.6305.

Kurniasari, F. (2017). Implementasi Pendekatan Saintifik Pada Penugasan Aktivitas Di Buku Teks Bahasa Indonesia Kelas VII SMP Berdasarkan Kurikulum 2013. Jurnal Pendidikan Edutama, 4(1), 9-26. https://doi.org/10.30734/jpe.v4i1.44.

Mahardika, B. (2018). Penerapan Metode Penilaian Berbasis Portofolio Dalam Meningkatkan Pembelajaran Bahasa Indonesia. Elementary: Jurnal Ilmiah Pendidikan Dasar, 4(1), 33-46. https://doi.org/10.32332/elementary.v4i1.1030.

Maharwati, N. K. (2019). Upaya Meningkatkan Kemampuan Berbahasa Lisan Anak Paud Berbantuan 
Media Gambar Melalui Metode Bercerita. Journal of Education Technology, 2(1), 6. https://doi.org/10.23887/jet.v2i1.13800.

Mayasari, S., \& N, L. (2019). Penerapan Model Pembelajaran Kooperatif Tipe Picture And Picture Untuk Meningkatkan Hasil Belajar IPS Siswa Kelas III SD Negeri 37 Pekanbaru. Jurnal Pajar (Pendidikan Dan Pengajaran), 3(2), 313-318. https://doi.org/10.33578/pjr.v3i2.6659.

Ningsih, I. H., Winarni, R., \& Roemintoyo. (2019). Peran Guru Dalam Pembelajaran Menulis Permulaan Menghadi Abad 21. BASINDO : Jurnal Kajian Bahasa, Sastra Indonesia, Dan Pembelajarannya, 3(1), 38-43. https://doi.org/10.17977/um007v3i12019p038.

Nugroho, A., Lazuardi, D. R., \& Murti, S. (2019). Pengembangan Bahan Ajar Lks Menulis Pantun Berbasis Kearifan Lokal Siswa Kelas Vii Smp Xaverius Tugumulyo. KEMBARA: Jurnal Keilmuan Bahasa, Sastra, Dan Pengajarannya, 5(1), 1. https://doi.org/10.22219/kembara.vol5.no1.1-12.

Owon, S., \& Adi, R. (2017). Pengembangan Bahan Ajar Menulis Berbagai Jenis Teks Bertema Kearifan Lokal Sikka Bagi Siswa SMP. JINoP (Jurnal Inovasi Pembelajaran), 3(1), 528-541. https://doi.org/10.22219/jinop.v3i1.4318.

Paramita, N. M. A. S., Rati, N. W., \& Tristiantari, N. K. D. (2019). Pengaruh Model Pembelajaran Picture And Picture Berorientasi Pendidikan Karakter Terhadap Motivasi Belajar Ips Siswa Kelas V. Journal Of Education Technology, 3(1), 1-8. https://doi.org/10.23887/Jet.V3i1.17957.

Passalowongi, N. (2020). Meningkatkan Hasil Belajar Tema Lingkungan Tempat Tinggalku Melalui Model Pembelajaran Picture and Picture Siswa Kelas IV SD Negeri 18 Coppeng-Coppeng Kabupaten Barru. Jurnal Studi Guru Dan Pembelajaran, 3(2), 275-282. https://doi.org/10.30605/jsgp.3.2.2020.341.

Puspidalia, Y. S. (2012). Problematika Pembelajaran Bahasa Indonesia Di Mi/Sd Dan Alternatif Pemecahannya. Cendekia: Jurnal Kependidikan Dan Kemasyarakatan, 10(1). https://doi.org/10.21154/cendekia.v10i1.406.

Rakasiwi, N. (2019). Pengembangan media komik dengan metode picture and picture untuk meningkatkan keterampilan literasi matematika kelas IV. Aksioma: Jurnal Matematika Dan Pendidikan Matematika, 10(1), 60-70. https://doi.org/10.26877/aks.v10i1.3741.

Riana, R., \& Setiadi, S. (2017). Penerapan Model Pembelajaran Kooperatif Teknik Mind Mapping Dalam Meningkatkan Keterampilan Menulis Karangan Narasi Ekspositoris Pada Mata Pelajaran Bahasa Indonesia Peserta Didik Kelas XII SMK Swadaya, Semarang. Jurnal Dinamika Sosial Budaya, 18(1), 109. https://doi.org/10.26623/jdsb.v18i1.562.

Rosini, N. M., Yudana, I. M., \& Agung, A. A. G. (2018). Kontribusi Kecerdasan Emosional, Kreativitas dan Keterlibatan Dalam Kegiatan MGMP Terhadap Keterampilan Mengelola Pembelajaran Bahasa Indonesia Para Guru SMA di Kabupaten Badung. Jurnal Administrasi Pendidikan Indonesia, 9(1), 33-43. https://doi.org/10.23887/japi.v9i1.2734.

Rosmalem. (2017). Peningkatan Aktivitas Belajar Siswa Dengan Model Pembelajaran Picture And Picture Pada Pelajaran Seni Budaya. Jurnal Handayani: Jurnal Kajian Pendidikan Pra Sekolah Dan Pendidikan Dasar, 6(2), 153-161. https://doi.org/10.24114/jh.v6i2.6529.

Said, I. M., Sutadji, E., \& Sugandi, M. (2019). Pengembangan Bahan Ajar Berbasis Cooperative Learning Dengan Pendekatan Saintifik Untuk Siswa Smk Se-Kota Malang Program Keahlian Teknik Ototronik. Jurnal Pendidikan: Teori, Penelitian Dan Pengembangan, 1(2), 265-270. https://doi.org/10.17977/jp.v1i2.6131.

Sribawana, I. P. S. S., Kusmariyatni, N., \& Suwatra, I. I. W. (2017). Pengaruh Model Pembelajaran Problem Based Learning Berbantuan Media Gambar Terhadap Hasil Belajar IPA Kelas IV. Mimbar PGSD Undiksha, 5(2), 1-12. https://doi.org/10.23887/jjpgsd.v5i2.10934.

Sudaryanto. (2014). Studi Tentang Perkembangan Bahasa Indonesia Di Tiongkok Dan Dampak Kesarjanaan Tiongkok Bagi Pengajaran Bahasa Indonesia. Kajian Linguistik Dan Sastra, 26(1), 61-70. https://doi.org/10.23917/kls.v26i1.4083.

Suhartini, S. (2015). Peningkatan Keterampilan Menulis Naskah Drama Satu Babak Menggunakan Model Think-Pair-Share Berbantuan Alat Peraga Gambar Berseri. Satya Widya, 31(2), 83-89. https://doi.org/10.24246/j.sw.2015.v31.i2.p83-89.

Susanti, P. A., \& Kusmariyani, N. N. (2017). Penerapan Model Picture And Picture Berbasis Pendekatan Saintifik Untuk Meningkatkan Hasil Pengetahuan IPA. Jurnal Ilmiah Sekolah Dasar, 1(2), 99. https://doi.org/10.23887/jisd.v1i2.10144.

Sutriyati, Mulawarman, W. G., \& Hudiyono, Y. (2019). Pengembangan Bahan Ajar Menulis Esai Dengan 
Memanfaatkan Kearifan Lokal Melalui Pembelajaran Berbasis Proyek (PBP) Siswa SMA. Diglosia, 2(1), 39-46. https://doi.org/10.30872/diglosia.v2i1.16.

Suwartini, I., \& Fujiastuti, A. (2017). Teknik Pembuatan Buku Ajar Membaca Kritis Dan Kreatif Berbasis Arcs (Attention, Relevance, Convidence, Satisfaction) Untuk Mahasiswa Pendidikan Bahasa Dan Sastra Indonesia. Bahastra, 37(2), 138-147. https://doi.org/10.26555/bahastra.v37i2.7610.

Tanjung, N. (2018). Peningkatan Hasil Belajar Ips Melalui Model Pembelajaran Kooperatif Picture and Picture Siswa Kelas V A SD Negeri 200402 Sabungan Padangsidimpuan 2017- 2018. Ristekdik: Jurnal Bimbingan Dan Konseling, 3(2), 45-48. https://doi.org/10.31604/Ristekdik.2018.V3i2.45-48.

Trisnawati, N. N. L., Suarni, N. K., \& Agung, A. A. G. (2014). Penerapan Metode Picture and Picture Dengan Media Cerita Gambar Berseri Untuk Meningkatkan Perkembangan Bahasa Anak. Journal PG-PAUD Universitas Pendidikan Ganesha, 2(1), 1-10. https://ejournal.undiksha.ac.id/index.php/JJPAUD/article/download/3149/2617.

Ulfah, D. M., \& Soenarto, S. (2017). Pengaruh penggunaan media video dan gambar terhadap keterampilan menulis kelas V. Jurnal Prima Edukasia, 5(1), 22-34. https://doi.org/10.21831/jpe.v5i1.7693.

Utama, M., \& Sari, D. L. (2015). Keefektifan Model Pembelajaran Picture And Picture Dan Make A Match Ditinjau Dari Hasil Belajar Dalam Pembelajaran IPA Kelas 4 SD Gugus Mawar - Suruh. Scholaria: Jurnal Pendidikan Dan Kebudayaan, 5(3), 82-99. https://doi.org/10.24246/j.scholaria.2015.v5.i3.p82-99.

Wahyuni, S. (2014). Pengembangan Interactive E-Book Bidang Asesmen Bahasa Untuk Mengembangkan Kompetensi Dan Kemandirian Mahasiswa Program Pendidikan Bahasa. Litera, 13(1), 128-139. https://doi.org/10.21831/ltr.v13i1.1908.

Yoserizal, \& Rahmi, U. (2019). Perbedaan Aktivitas Belajar Siswa Antara Model Cooperative Learning Tipe Snowball Throwing Dengan Tipe Think Pair Share. Jurnal Basicedu, 3(2), 1055-1064. https://doi.org/10.31004/basicedu.v3i4.247.

Yuanta, F. (2017). Pengembangan Media Audio Visual Mata Pelajaran Bahasa Indonesia Untuk Sekolah Dasar. Ibriez: Jurnal Kependidikan Dasar Islam Berbasis Sains, 2(2), 59-70. https://doi.org/10.21154/ibriez.v2i2.36. 